\title{
Pemetaan Tingkat Kerawanan Longsor Berdasarkan Curah Hujan dan Geologi Menggunakan Metode Fuzzy Logic Di Kecamatan Leupung Kabupaten Aceh Besar \\ (Mapping Landslide Level Based on Rainfall and Geology Using Fuzzy Logic Method in Leupung Sub-district, Aceh Besar District)
}

\author{
Rasyid Alkhoir Lubis ${ }^{1}$, Muhammad Rusdi ${ }^{1}$, Hairul Basri ${ }^{1 *}$ \\ ${ }^{1}$ Program Studi Ilmu Tanah, Fakultas Pertanian, Universitas Syiah Kuala \\ Email : lubisrasyid@gmail.com
}

\begin{abstract}
Abstrak. Penelitian ini bertujuan untuk mengetahui tingkat kerawanan longsor di Kecamatan Leupung Kabupaten Aceh Besar. Penelitian ini dilakukan menggunakan SIG dengan Metode Fuzzy Logic. Curah Hujan dan Geologi sebagai variabel input dan tingkat kerawanan longsor sebagai variabel output metode fuzzy logic. Beberapa tahapan yang dilakukan dalam metode ini antara lain: fuzzyfication, inferensi dan defuzzyfication. Secara umum, tahapan penelitian persiapan, pra analisis data, analisis data dan output. Penelitian ini dilakukan karena Kecamatan Leupung berbukit, berlereng, tersusun dari material sedimen termasuk batuan pegunungan dan memiliki curah hujan yang lebih tinggi dibandingkan dengan kecamatan lainnya di lingkup Kabupaten Aceh Besar.Hasil penelitian memperoleh hasil bahwa Kecamatan Leupung didominasi dengan tingkat kerawanan longsor kategori rendah dan sedang. Tingkat kerawanan longsor rendah seluas $16.486,01$ ha $(97,97 \%)$ dan tingkat kerawanan longsor sedang seluas 342,37 ha $(2,03 \%)$. Kedua faktor yaitu curah hujan dan geologi saling mempengaruhi sehingga membedakan nilai defuzzyfication serta kelas kerawanan longsor.
\end{abstract}

Kata kunci : Tingkat Kerawanan Longsor, Curah Hujan, Geologi, Fuzzy Logic, SIG

\begin{abstract}
This study aims to determine the level of landslide vulnerability in Leupung District, Aceh Besar District. This research was conducted using GIS with Fuzzy Logic Method. Rainfall and Geology as input variables and landslide vulnerability as output variables fuzzy logic method. Some of the steps performed in this method include: fuzzyfication, inference and defuzzyfication. In general, the stages of preparatory research, pre-data analysis, data analysis and output. This research was conducted because the hilly Leupung District, the slopes, composed of sedimentary materials including mountainous rocks and had higher rainfall compared to other sub-districts in Aceh Besar. The result of this research is that Leupung District is dominated by low and medium category avalanche vulnerability. Low landslide vulnerability of 16,486.01 ha $(97.97 \%)$ and moderate landslide vulnerability of 342.37 ha (2.03\%). Both factors are rainfall and geology influence each other so as to distinguish the defuzzyfication value and the class of landslide vulnerability.
\end{abstract}

Keywords: Landslide Avalanche, Rainfall, Geology, Fuzzy Logic, SIG

\section{PENDAHULUAN}

Bencana merupakan kejadian yang mengganggu aktivitas kehiduan manusia dan bersifat merugikan daerah yang didiaminya (Sudibyakto, 2009). Longsor merupakan salah satu bencana alam yang kerap terjadi di Indonesia dalam setiap tahunnya di berbagai daerah (BNPB, 2017). Bencana longsor merugikan bermacam aspek kehidupan termasuk berdampak pada lahan pertanian, sosial ekonomis daerah hingga menimbulkan korban jiwa.

Kecamatan leupung merupakan salah satu kecamatan Provinsi Aceh dan terletak di Kabupaten Aceh Besar yang telah terjadi beberapa kali bencana longsor di tahun yang berbeda-beda maupun dibulan yang berbeda di tahun yang sama. Longsor yang terjadi diduga diakibatkan oleh bentuk lahan Kecamatan Leupung berbukit, berlereng, tersusun 
dari material sedimen termasuk batuan pegunungan dan memiliki curah hujan yang lebih tinggi dibandingkan dengan kecamatan lainnya di lingkup Kabupaten Aceh Besar.

Karnawati (2003) menyatakan salah satu faktor penyebab terjadinya bencana tanah longsor adalah air hujan. Air hujan yang telah meresap ke dalam tanah dan derasnya hujan mengakibatkan air yang tertahan semakin meningkatkan debit dan volumenya. Batuan yang kompak dan kedap air berperan sebagai penahan air dan sekaligus sebagai bidang gelincir longsoran, sedangkan air berperan sebagai penggerak massa tanah yang tergelincir di atas batuan kompak tersebut.

Faktor geologi yang memicu terjadinya suatu longsor ditentukan oleh struktur batuan dan komposisi mineralogi yang berpengaruh terhadap kepekaan erosi dan longsor yang dicirikan dengan jenis batuan (Lestari, 2008). Mengingat hal tersebut diatas, diperlukan pemetaan tingkat kerawanan longsor sebagai informasi yang akan menjadi tindakan awal pencegahan longsor dan mengurangi kerugian daerah hingga tangguh terhadap akan terjadinya bencana longsor. Dalam penelitian ini pemetaan ditinjau berdasarkan faktor curah hujan dan geologi sebagai faktor yang diduga sangat mempengaruhi terjadinya longsor. Untuk penentuan tingkat kerawanannya digunakan metode fuzzy logic dan pemetaannya dilakukan menggunakan SIG.

\section{METODE PENELITIAN}

Penelitian ini dilaksanakan mulai Agustus hingga Oktober 2017. Lokasi kajian penelitian di Kecamatan Leupung Kabupaten Aceh Besar sedangkan pengolahan data dilakukan di Laboratorium Penginderaan Jauh dan Kartografi Program Studi Ilmu Tanah Universitas Syiah Kuala.

Alat-alat yang digunakan dalam penelitian ini antara lain: GPS, komputer, printer dan kamera sebagai perangkat keras dan ArcGIS, MATLAB dan Ms. Office sebagai perangkat lunak. Bahan - Bahan yang digunakan dalam penelitian ini antara lain peta digital administrasi Kecamatan Leupung (Bappeda Aceh, 2015), Data curah hujan 6 penakar hujan di Kecamatan Kabupaten Aceh Besar sebagai pengikat Kecamatan Leupung (BMKG, 2017), dan Peta digital Geologi Kecamatan Leupung (Distamben Aceh, 1981).

Penelitian ini dilakukan dengan prinsip metode deskriptif yaitu metode yang dilakukan dengan tujuan membandingkan beberapa faktor dan mengetahui kondisi lapangan tertentu saat ini (Mardalis, 2003). Penelitian ini menggunakan satuan unit lahan sebagai satuan analisis yang digunakan untuk menilai dan menentukan tingkat kerawanan longsor. Penentuan tingkat kerawanan longsor dilakukan menggunakan metode Fuzzy Logic dengan penerapkan metode Direktorat Vulkanologi dan Mitigasi Bencana Geologi Tahun 2004 pada tahapan inferensi. Logika fuzzy adalah suatu cara yang tepat untuk memetakan suatu ruang input ke dalam suatu ruang output. Teori himpunan logika samar ini dikembangkan oleh Prof. Lofti Zadeh pada tahun 1965. Zadeh berpendapat bahwa logika benar dan salah dalam logika konvensional tidak dapat mengatasi masalah gradasi yang berada pada dunia nyata. Tidak seperti logika boolean, logika fuzzy mempunyai nilai yang kontinue. Samar dinyatakan dalam derajat dari suatu keanggotaan dan derajat dari kebenaran. Oleh sebab itu, sesuatu dapat dikatakan sebagian benar dan sebagian salah pada waktu yang sama (Al Hakim, 2010).

Beberapa tahapan dalam penelitian ini antara lain: persiapan, pra analisis data, analisis data dan output. Persiapan merupakan tahapan penggalian informasi terkait penelitian dari berbagai sumber seperti peraturan pemerintah, skripsi, tesis, jurnal maupun 
jenis lainnya serta pengumpulan data sekunder yang menjadi bahan dalam penelitian ini dari dinas- dinas terkait.

Pra analisis data merupakan tahapan penelitian yang dilakukan untuk pengolahan data mentah menjadi bahan yang dapat digunakan dalam tahapan selanjutnya yaitu tahapan analisis data. Dalam tahap ini, dilakukan pengolahan data 6 penakar hujan di kecamatan berbeda di Kabupaten Aceh besar menggunakan sistem klasifikasi SK Mentan Nomor: 837/Kpts/Um/11/1980 hingga menghasilkan peta curah hujan Kecamatan Leupung Tahun 2017.

Analisis data merupakan tahapan pengolahan bahan bahan penelitian hingga menjadi hasil. Pada tahapan ini, analisis dilakukan dengan sistem analisis spasial. Pada tahapan ini dilakukan penentuan satuan unit lahan dan penentuan tingkat kerawanan longsor. Penentuan satuan unit lahan dilakukan dengan menumpang tindihkan peta digital curah hujan dan geologi kecamatan leupung pada software ArcGIS.

Penentuan tingkat kerawanan longsor dilakukan menggunakan metode fuzzy logic. Beberapa tahapan yang dilakukan pada metide ini antara lain: fuzzyfication, inferensi dan deffuzification.

Fuzzyfication adalah tahap mengkorversikan nilai asli faktor penentu longsor menjadi suatu nilai baru dan disebut nilai fuzzy. Dalam tahap ini, penggambaran grafik menggunakan pendekatan grafik kurva segitiga dengan interval himpunan semesta 0-100 untuk variabel input maupun variabel output.

Inferensi merupakan tahapan penerapan aturan aturan fuzzy kedalam sistem dan sebagai pertimbangan fuzzy dalam penarikan kesimpulan pada tahap selanjutnya yaitu deffuzyfication. Pada tahap inferensi penelitian ini penulis menggunakan inferensi model mamdani. Aturan aturan fuzzy dalam penelitian ini diperoleh melalui penskoran nilai curah hujan dan geologi pada masing masing satuan unit lahan dengan menggunakan metode Direktorat Vulkanologi dan Mitigasi Bencana Geologi/ DVMBG Tahun 2004 dalam Effendi (2008)

Deffuzification adalah tahap akhir metode fuzzy logic. Tahapan ini dilakukan dengan metode centroid. Dimana tahap ini dilakukan penginputan nilai fuzzy setiap satuan unit lahan dan perolehan nilai output fuzzy sebagai nilai tingkat kerawanan longsor.

Output merupakan tahapan akhir penelitian ini. Pada tahap akhir penelitian, dilakukan pengklasifikasian tingkat kerawanan longsor dengan menggunakan nilai output fuzzy dan melihat kurva segitiga fuzzyfication sebagai acuannya. Setelah klasifikasi setiap satuan uni lahan diperoleh, dilakukan pemetaan tingkat kerawanan longsor Kecamatan Leupung.

\section{HASIL DAN PEMBAHASAN}

\section{Curah Hujan Kecamatan Leupung}

Berdasarkan data 6 penakar hujan dengan kecamatan berbeda dan pengklasifikasian menggunakan SK Mentan Nomor : 837/Kpts/Um/11/1980 serta penggambaran penyebaran curah hujan dengan konsep interpolation dan kaedah Inverse Distance Weighted (IDW) pada ArcGIS diperoleh hasil penyebaran curah hujan rata-rata/ hari hujan disajikan secara spasial pada Gambar 1. dan secara tabular dilengkapi luasan disajikan pada Tabel 1. 


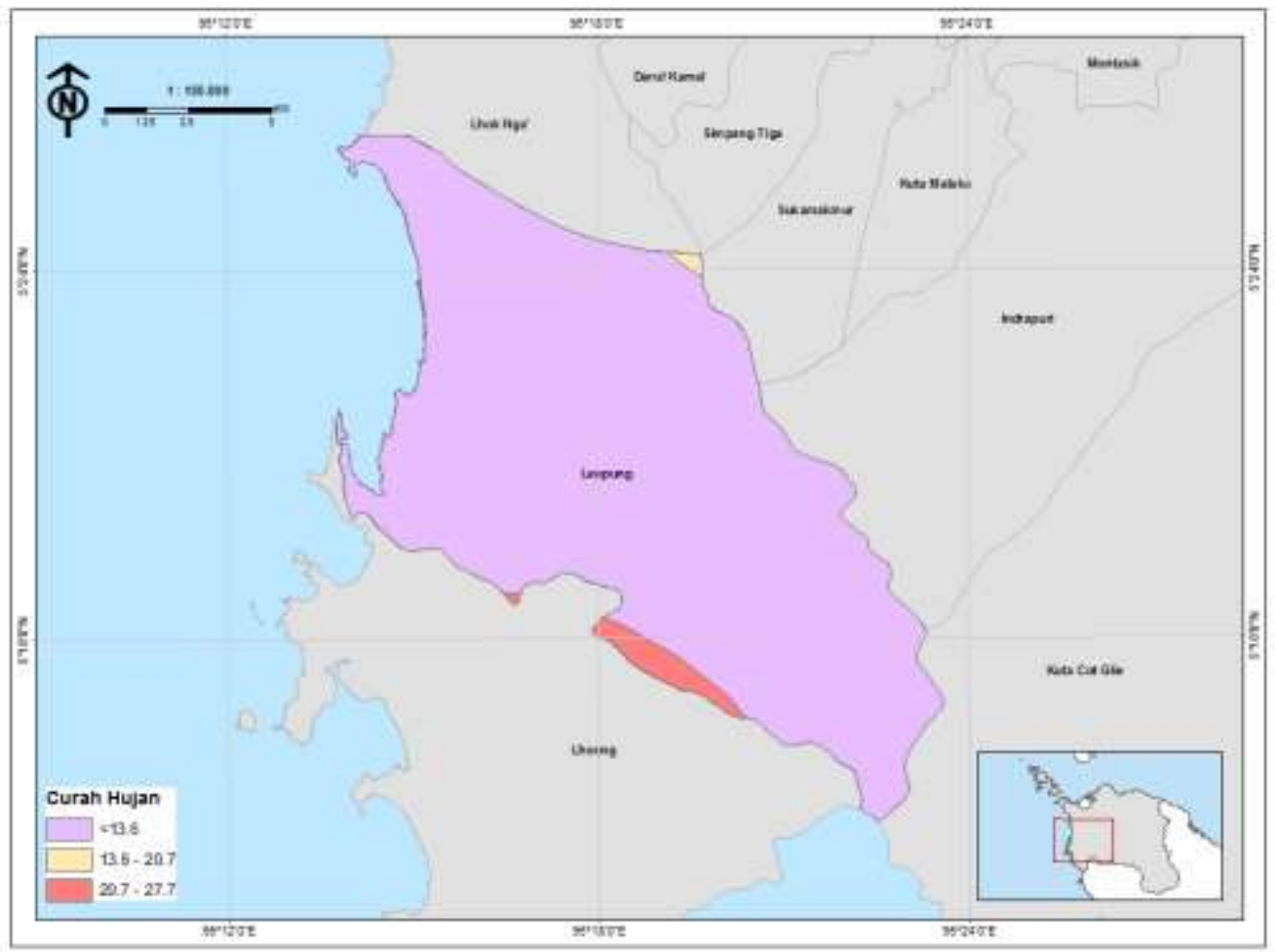

Gambar 1. Curah Hujan Kecamatan Leupung

Tabel 1. Luas Curah Hujan Kecamatan Leupung

\begin{tabular}{clrr}
\hline \multirow{2}{*}{ No. } & Intensitas Curah Hujan $(\mathrm{mm} /$ hari & \multicolumn{2}{c}{ Luas } \\
\cline { 3 - 4 } hujan) & & (ha) & $(\%)$ \\
\hline 1. & $<13,6$ & $16.449,40$ & 97,75 \\
2. & $13,6-20,7$ & 36,61 & 0,22 \\
3. & $20,7-27,7$ & 342,37 & 2,03 \\
\hline & Jumlah & $16.828,38$ & 100 \\
\hline
\end{tabular}

Sumber : Hasil analisis (2017)

Berdasarkan Tabel 1. diketahui bahwa intensitas curah hujan $<13.6 \mathrm{~mm} /$ hari hujan mendominasi Kecamatan Leupung dengan pesentase 97,75 \%, hal ini menerangkan bahwa Kecamatan Leupung memiliki curah hujan rata-rata harian yang tergolong sangat rendah dan selanjutnya diikuti oleh intensitas curah hujan $20,7-27,7 \mathrm{~mm} /$ hari hujan dengan persentase 2,03\% dari Kecamatan Leupung yang tersebar di daerah selatan Kecamatan Leupung dan intensitas curah hujan 13,6-20,7 $\mathrm{mm} /$ hari hujan tersebar di daerah utara Kecamatan Leupung.

\section{Geologi Kecamatan Leupung}

Berdasarkan peta digital yang diperoleh dari Dinas Energi dan Sumberdaya Mineral Provinsi Aceh, geologi Kecamatan Leupung dikelompokkan menjadi enam jenis batuan. Enam jenis batuan tersebut merupakan batuan golongan batuan alluvial, batuan sedimen dan batuan vulkanik. 
Jenis batuan yang berbeda yang berasal dari komposisi batuan yang berbeda memiliki struktur batuan, tekstur dan sifat batuan yang berbeda pula. Setelah luas geologi direkapitulasi dan disajikan pada Tabel 2, terlihat bahwa geologi yang mendominasi pada Kecamatan Leupung yaitu geologi yang tersusun oleh komposisi anggota terumbu dengan luas sebesar $10.188,39$ ha $(60,54 \%)$ sedangkan geologi dengan luasan terkecil yaitu geologi yang tesusun oleh komposisi formasi batugamping lamno yang memiliki luasan sebesar 129,69 ha $(0,77 \%)$ dari luas keseluruhan Kecamatan Leupung. Sebaran secara spasial geologi Kecamatan Leupung disajikan pada Gambar 2.

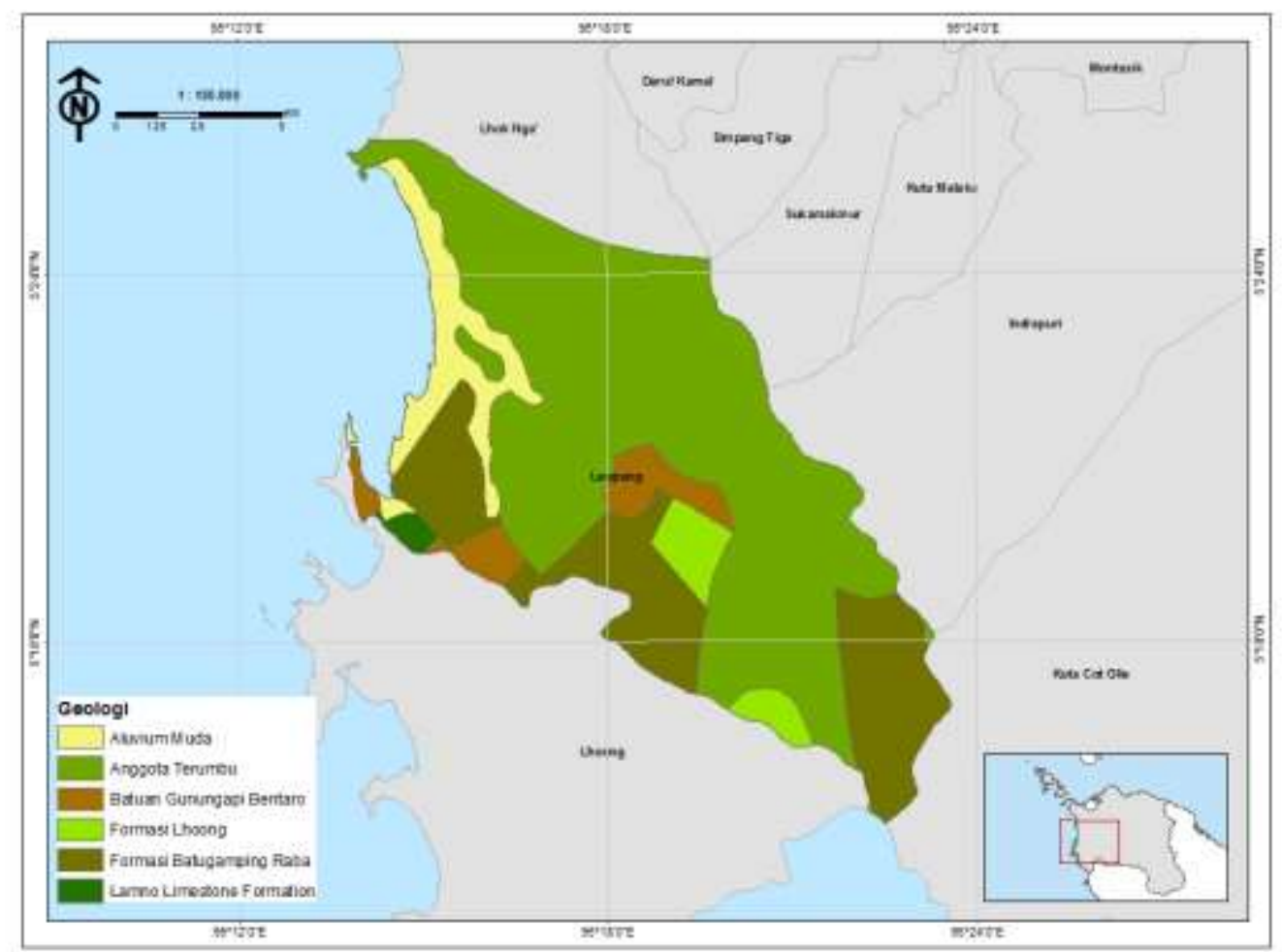

Gambar 2. Geologi Kecamatan Leupung

Tabel 2. Luas Geologi Kecamatan Leupung

\begin{tabular}{clrr}
\hline \multirow{2}{*}{ No. } & \multicolumn{1}{c}{ Geologi } & \multicolumn{2}{c}{ Luas } \\
\cline { 3 - 4 } & & $1.280,30$ & \multicolumn{1}{c}{ (\%) } \\
\hline 1. & Aluvium Muda & $10.188,39$ & 60,54 \\
2. & Anggota Terumbu & 828,53 & 4,92 \\
3. & Batuan Gunungapi Bentaro & 129,69 & 0,77 \\
4. & Formasi Batugamping Lamno & $3.738,27$ & 22,21 \\
5. & Formasi Batugamping Raba & 663,20 & 3,94 \\
6. & Formasi Lhoong Jumlah & $16.828,38$ & 100 \\
\hline
\end{tabular}

Sumber : Hasil analisis (2017) 


\section{Satuan Unit Lahan}

Setelah dilakukan tumpang tindih peta digital curah hujan dan geologi kecamatan leupung diperoleh 10 satuan unit lahan. Keragaman dan banyak satuan unit lahan menggambarkan perbedaan satuan lahan satu sama lain. Sejalan dengan Akhsar (2013) dalam penelitiannya dimana pemilihan sejumlah item tertentu dari seluruh item yang ada dengan tujuan mempelajari sebagian item tersebut untuk mewakili seluruh itemnya. Sebagian item yang dipilih disebut sampel dan pada penelitian ini disebut satuan unit lahan. Deskripsi satuan unit lahan secara terperinci disajikan pada Tabel 3.

Tabel 3. Satuan Unit Lahan

\begin{tabular}{|c|c|c|c|c|}
\hline \multirow{2}{*}{$\begin{array}{l}\text { Satuan } \\
\text { Unit } \\
\text { Lahan }\end{array}$} & \multirow{2}{*}{$\begin{array}{c}\text { Intensitas Curah } \\
\text { Hujan (mm/hari } \\
\text { hujan) }\end{array}$} & \multirow[b]{2}{*}{ Geologi } & \multicolumn{2}{|c|}{ Luas } \\
\hline & & & (ha) & $(\%)$ \\
\hline 1 & 13.6 & Aluvium Muda & 1280.3 & 7.61 \\
\hline 2 & 13.6 & Anggota Terumbu & 10088.06 & 59.95 \\
\hline 3 & 13.6 & Formasi Batugamping Raba & 3481.08 & 20.69 \\
\hline 4 & 13.6 & Batuan Gunungapi Bentaro & 828.53 & 4.92 \\
\hline 5 & 13.6 & Formasi Lhoong & 641.75 & 3.81 \\
\hline 6 & 13.6 & Formasi Batugamping Lamno & 129.69 & 0.77 \\
\hline 7 & 20.7 & Anggota Terumbu & 36.61 & 0.22 \\
\hline 8 & 27.7 & Anggota Terumbu & 63.73 & 0.38 \\
\hline 9 & 27.7 & Formasi Batugamping Raba & 257.19 & 1.53 \\
\hline 10 & 27.7 & Formasi Lhoong & 21.45 & 0.13 \\
\hline
\end{tabular}

Sumber: Analisis (2017)

\section{Analisis Tingkat Kerawanan Longsor}

Telah dilakukan beberapa tahapan fuzzy logic mulai fuzzyfication, inferensi, dan defuzzyfication. Dari lima kelas klasifikasi yang direncanakan antara lain : sangat rendah, rendah, sedang, tinggi dan sangat tinggi. Kecamatan Leupung Kabupaten Aceh Besar berdasarkan curah hujan dan geologi hanya memiliki dua tingkat kerawanan longsor yaitu tingkat kerawanan rendah dan sedang.

Kecamatan Leupung didominasi oleh tingkat kerawanan rendah seluas 16.486,01 ha $(97.97 \%)$ dan selanjutnya hanya diikuti tingkat kerawanan sedang dengan luasan 342,37 ha $(2,03 \%)$. Tingkat kerawanan rendah didominasi oleh curah hujan dengan intensitas $<13,6 \mathrm{~mm}$ dan dilihat dari segi geologi tersebar seluruh jenis batuan antara lain alluvial, sedimen hingga vulkanik yaitu anggota terumbu, alluvium muda, formasi batugamping raba, formasi lhoong, formasi batu gamping lamno, batuan gunungapi bentaro tersebar.

Daerah sebaran tingkat kerawanan sedang didominasi dengan intensitas curah hujan 20,7 - 27,7 $\mathrm{mm}$ dan ditinjau dari geologi tersebar geologi dengan jenis batuan yang berasal dari batuan sedimen yaitu formasi batugamping raba dan formasi lhoong dan batuan berasal dari batuan alluvial yaitu anggota terumbu. Secara spasial penyebaran tingkat kerawanan longsor Kecamatan Leupung disajikan pada Gambar 3. Untuk luasan secara rinci tingkat kerawanan longsor Kecamatan Leupung disajikan pada Tabel 4. 


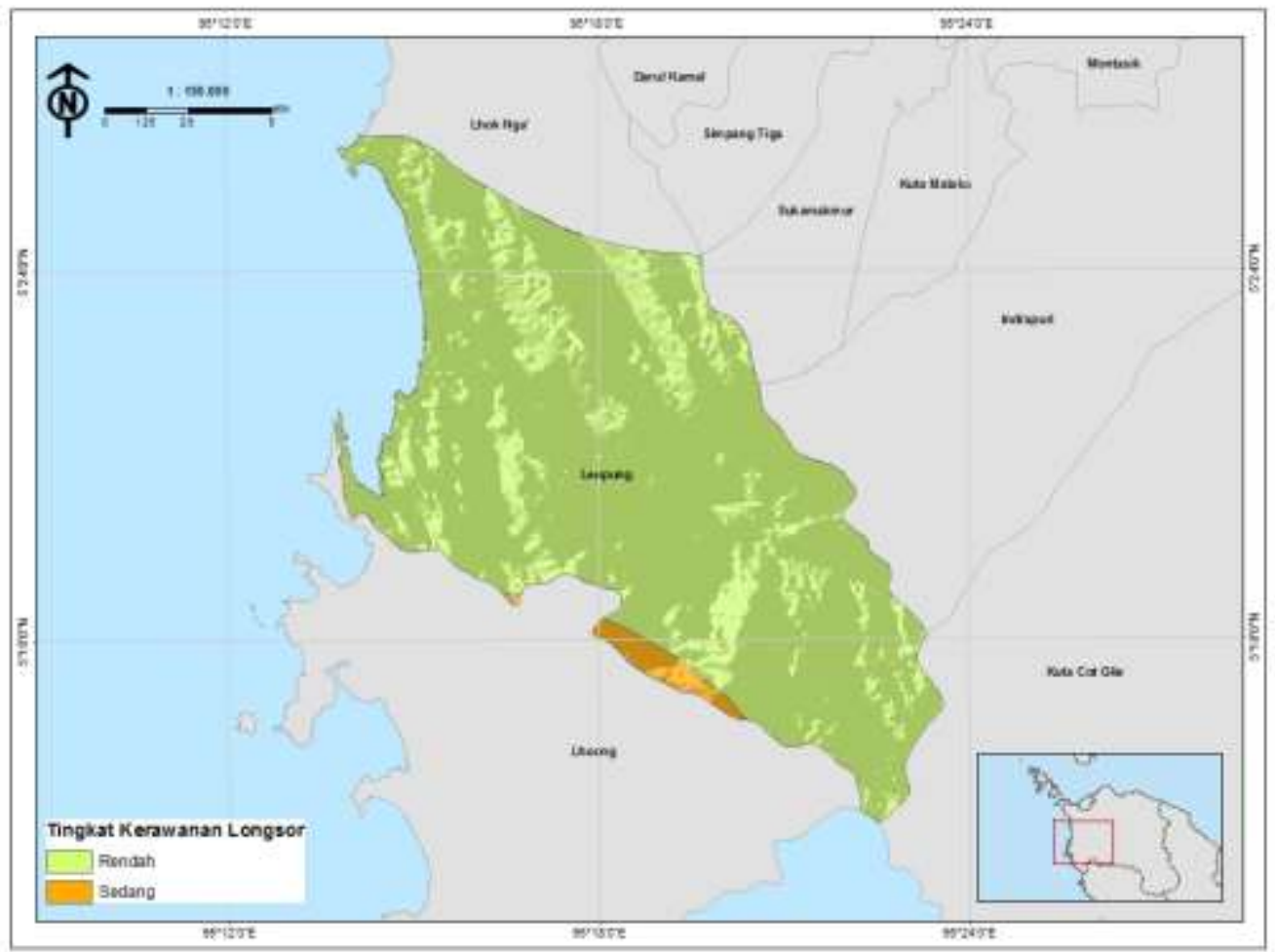

Gambar 3. Tingkat Kerawanan Longsor Kecamatan Leupung

Tabel 4. Luas Tingkat Kerawanan Longsor Kecamatan Leupung

No. Tingkat Kerawanan Longsor

Luas

(ha)

$(\%)$

\begin{tabular}{rrrr}
\hline 1 & Rendah & 16486.01 & 97.97 \\
2 & Sedang & 342.37 & 2.03 \\
\hline & Jumlah & 16828.38 & 100 \\
\hline
\end{tabular}

Sumber : Analisis (2017)

\section{KESIMPULAN}

Tingkat kerawanan longsor Kecamatan Leupung berdasarkan curah hujan dan geologi memiliki kategori rendah dan sedang. Tingkat kerawanan longsor rendah seluas 16.486,01 ha (97,97 \%) dan tingkat kerawanan longsor sedang seluas 342,37 ha (2,03\%). Kedua faktor yaitu curah hujan dan geologi saling mempengaruhi sehingga membedakan nilai defuzzyfication serta kelas kerawanan longsor. Terjadi perbedaan nyata pergerakan kelas kerwanan longsor pada kelas curah hujan dari <13,6 mm ke intensitas 13,6 -20,7 mm maupun 20,7 - 27,7 mm di beberapa satuan unit lahan. 


\section{DAFTAR PUSTAKA}

Al-Hakim, J. 2010. Perancangan Prediktor Cuaca Maritim Dengan Metode Logika Fuzzy Untuk Meningkatkan Jangkauan Ramalan: Studi Kasus Pelayaran SurabayaBanjarmasin. Surabaya: Jurusan Teknik Fisika. Institut Teknologi Sepuluh Nopember.

Effendi, A.D. 2008. Identifikasi Kejadian Longsor Dan Penentuan Faktor-Faktor Utama Penyebabnya Di Kecamatan Babakan Madang Kabupaten Bogor. Skripsi. Departemen Manajemen Hutan. Fakultas Kehutanan, Institut Pertanian Bogor.

Karnawati, D. 2003. Himbauan Untuk Antisipasi Longsoran Susulan. Tim Longsoran Teknik Geologi UGM Yogyakarta. Tidak Diterbitkan.

Lestari, F.F. 2008. Penerapan Sistem Informasi Geografis Dalam Pemetaan Daerah Rawan Longsor Di Kabupaten Bogor. Skripsi. Departemen Manajemen Hutan. Fakultas Kehutanan, Institut Pertanian Bogor.

Mardalis. 2003. Metode Penelitian Suatu Pendekatan Proposal. Vol 6. Jakarta: PT Bumi Aksara.

Mentan. 1980. Surat Keputusan Menteri Pertanian Republik Indonesia No 837/Kpts/Um/11/1980. Menteri Pertanian. Jakarta.

Sudibyakto. 2009. Jurnal Kebencanaan Indonesia Vol. 2/No.1: Pengembangan Sistem Perencanaan Manajemen Risiko Bencana di Indonesia. Yogyakarta: PSBA Universitas Gadjah Mada 